\title{
The reverse mortgage: a tool for funding long-term care and increasing public housing supply in Spain
}

\author{
Roberto Martinez-Lacoba ${ }^{1,2,4,5}$ (D) Isabel Pardo-Garcia ${ }^{1,3,4,5}$. \\ Francisco Escribano-Sotos ${ }^{1,2,4,5}$
}

Received: 14 January 2020 / Accepted: 3 November 2020 / Published online: 16 November 2020 (c) Springer Nature B.V. 2020

\begin{abstract}
Population ageing is one of the most significant challenges facing the world in the twentyfirst century. Furthermore, people aged over 65 typically have a level of income below the national average, but the homeownership rate among those in this age group tends to be high. Equity release schemes, specifically reverse mortgages, can help cover increased care costs and ensure a reasonable level of income, thus guaranteeing the well-being of older adults. However, this product has not been greatly developed by private entities. If the State were to implement this financial operation through public administrations, it could obtain homes that might then be included in public housing stocks. Thus, our paper aims to contribute to the literature on government-based reverse mortgage systems. Under our assumptions, the results showed that if 313,833 homes were reverse-mortgaged, the investment by the public administration would be around $0.73 \%$ GDP, with this being a feasible proposal. This work helps to create alternative methods to finance problems related with the ageing of societies from a public perspective.
\end{abstract}

Keywords Reverse mortgage $\cdot$ Public finance $\cdot$ Housing $\cdot$ Ageing $\cdot$ Dependency $\cdot$ Welfare state

Roberto Martinez-Lacoba roberto.mlacoba@uclm.es

Isabel Pardo-Garcia isabel.pardo@uclm.es

Francisco Escribano-Sotos

francisco.esotos@uclm.es

1 Facultad de Ciencias Económicas y Empresariales, Universidad de Castilla-La Mancha, Ciudad Real, Spain

2 Departamento de Análisis Económico y Finanzas, Universidad de Castilla-La Mancha, Ciudad Real, Spain

3 Departamento de Economía Política, Hacienda Pública, Estadística Económica y Empresarial y Política Económica, Universidad de Castilla-La Mancha, Ciudad Real, Spain

4 Centro de Estudios Sociosanitarios (CESS), Universidad de Castilla-La Mancha, Ciudad Real, Spain

5 Grupo de Investigación en Economía, Alimentación y Sociedad (GEAS), Universidad de CastillaLa Mancha, Ciudad Real, Spain 


\section{Introduction}

The demographic changes to come during the twenty-first century, created by rising life expectancy and a falling fertility rate, represent a challenge for society due to the increase in demand for care. The population of the most industrialized countries is ageing, with a growing number of people aged 85 and over, the oldest age group (Colombo et al. 2011). The Directorate-General for Economic and Financial Affairs of the European Commission believes these changes could affect the sustainability of public finances (European Commission 2018), and has consequently analysed long-term budget estimates based on the most recent population projections provided by Eurostat. According to this report, the percentage of dependent elderly people will increase significantly in the coming decades, ${ }^{1}$ from $29.6 \%$ in 2016 to a possible $51.2 \%$ in 2070 . These demographic changes may lead to variations in the dynamics of consumption, saving and investment at global level (Piggott and Woodland 2016).

The public policies, specifically welfare policies, impacted by population ageing can be grouped into policies on health, long-term care and pensions. In health, we can highlight the greater burden of the older population in primary care, with an increasing frequency of recourse to the service and a longer average hospital stay. In this sense, the projected increase in public expenditure on health care due to demographic change is almost $1 \%$ of gross domestic product for the EU-27 over 2016-2070 (European Commission 2018). In dependency, in both the public and private sphere, the response to the growing need for services has been insufficient to guarantee long-term care services, generating an increase in expenditure by both public institutions and the families with dependent individuals at home. On average across OECD countries, long-term care expenditure will reach $2.5 \%$ of GDP in 2060 (de la Maisonneuve and Oliveira Martins 2015). If we add to this the changes in family structure, the growing distance between parents and their children, the increasing number of people living alone and the integration of women into the labour market, the supply of informal care, that is, the attention to dependent persons provided by family and friends, is declining notably. The combination of population ageing and social changes, which will advance in coming years, means the demand for formal long-term care services will significantly increase, making care one of the sectors with the highest expected growth rate. With regard to pension policies in OECD countries, the old-age dependency ratio-number of individuals aged 65 and over per 100 people of working age defined as those aged between 20 and 64-will more than double by 2075 (OECD 2017a). In the EU, public pension expenditure is projected to increase by $0.8 \%$ of GDP between 2016 and 2040 (European Commission 2018). To alleviate public budgets some countries have implemented reforms in their pension and long-term care systems. For instance, some countries have considered (or are considering) a rise in the statutory retirement age (OECD 2017b) - e.g., in the Netherlands the retirement age is to increase to 67 and three months in 2022 .

The demographic factor has also a significant impact on the analysis of economic behaviour. The structure of preferences, needs and productive capacity of each of the cohorts that make up the population pyramid is not the same (see Fig. 1). From an economic perspective, the changes in the structure by age has effects linked to the generation of wealth, production, and consumption, such as saving and asset ownership. The population over the age

${ }^{1}$ Number of persons aged over 65 years with respect to the number aged between 15 and 64 . 


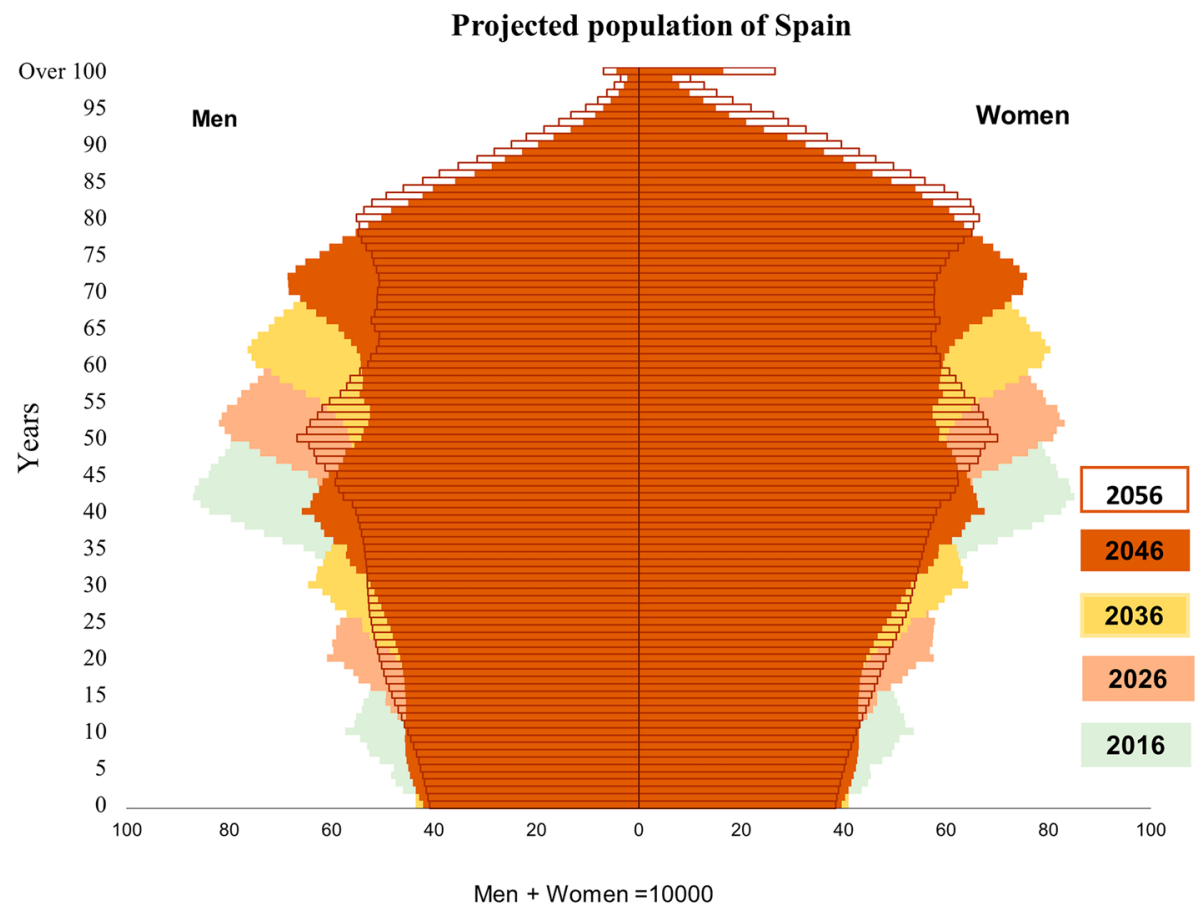

Fig. 1 Projected population pyramids in Spain (2016-2056). Source: Own preparation based on data from the Spanish National Statistics Institute

of 65 consumes public resources and services, but also actively participates in economic activity in the form of consumption, saving and investment. Generally, these individuals face changes in their incomes and expense profiles. On the expenses side, they could suffer financial shocks related to health (De Nardi et al. 2010) and long-term care expenditure. The out-of-pocket payments related to these shocks put the elderly at risk of poverty and catastrophic cost (del Pozo-Rubio et al. 2019). Aiming to meet unforeseen expense needs and to safeguard an adequate level of consumption and well-being for older and/or dependent adults, whose income tends to be lower in mean terms than the rest of the population (OECD 2017a), we need to find other alternatives that complement those already existing, such as pensions, private saving, health insurance and informal care (Eggleston and Mukherjee 2019).

\subsection{Housing, equity release schemes and reverse mortgage: a government-based approach}

Traditionally, the literature on retirement saving products has focused on bonds, asset portfolios for retirement, life insurance and long-term care insurance, among others (Dushi and Webb 2004; Inkmann et al. 2011; Koijen et al. 2016; Pashchenko 2013; Piggott and Woodland 2016; Turra and Mitchell 2007; Yaari 1965; Yogo 2016). Along with savings, housing can be considered a source of income for retirement, because the elderly are typically considered income-poor but asset-rich (Ong 2008) and one of the most common assets 
among older persons is their home (Coda Moscarola et al. 2015). For this reason equity release schemes could help to ensure income in old-age, because these types of schemes allow homeowners to extract income from their housing wealth in order to support financing needs at different moments of life (OECD 2013). However, using these schemes, which belong to asset-based welfare, is subject to other considerations. These schemes can be useful-e.g. to develop policies looking for the sustainability of pension and long-term care systems, but there are differences in the concentration of housing wealth that would limit the scope of these policies. In addition, they also depend on the evolution of the economic cycle (Mudrazija and Butrica 2017). There is also a debate about homeownership in Western societies: from housing as a service to housing as a commodity, changing the social objectives of the asset-based welfare into a neoliberal project (Simón-Moreno 2019).

Thus, reverse mortgage loans or reverse mortgages could be a valuable retirement planning tool, and they allow homeowners to borrow against their home equity, while still maintaining ownership of the home until they die (Piggott and Woodland 2016). The legal framework varies across countries: Australia, United States, Italy or Spain have regulated reverse mortgages, but other countries show voluntary codes-New Zealand-or just offer protection in the pre-contractual stage-Ireland or United Kingdom (ASIC 2018; SimónMoreno 2019). Authors such as Haurin et al. (2016), Michelangeli (2010), Redfoot et al. (2007) or Shan (2011) have analysed the characteristics of the borrowers of reverse mortgages and in what conditions this operation could be beneficial for them. For reverse mortgage loans, Nakajima and Telyukova (2017) showed that inheritance motives, uncertainty about health and expenses, and loan costs account for the low demand, and Costa-Font et al. (2010) found that current income, educational level, gender, and age are the main determinants of taking out a reverse mortgage loan. Despite the reverse mortgage being a promising policy tool, various market failures and risks constrain both supply-e.g. adverse selection-and demand-e.g. abuse concerns, creating small and shallow markets (Knaack et al. 2020). Generally, reverse mortgage loans or reverse mortgages have been the subject of growing attention in the literature but, to the best of our knowledge, the role of the State as a provider has not been analysed. Because private markets of reverse mortgages have not been greatly developed, the support or intervention of the government is needed. Our paper makes various contributions to the empirical knowledge on reverse mortgages. It quantifies the budgetary impact for the government, and the study is complemented by an estimation of the total monthly income such older adults would receive, taking into account the revenue obtained from the transaction, considering different scenarios. Additionally, it also presents a scenario in which the public administration is as a possible manager of a stock of public housing intended for social purposes.

In short, older adults may need additional income to tackle unforeseen expenses and to maintain an adequate level of consumption. Reverse mortgages are useful to complement income in old age but are products that have been underdeveloped by private entities. Thus, the aim of our study is to investigate reverse mortgage systems and the work contributes to the gap in the literature on government-based reverse mortgages. Specifically, we construct a theoretical model that permits the equity release of residential property via state intervention. 


\subsection{The case of Spain}

We apply this model to Spain. In this country, reverse mortgages have been regulated since 2007 under Law 41/2007 (Banco de España 2017a), ${ }^{2}$ and are focused on persons above 65 years or with a recognised level of disability or dependence. Nonetheless, as in other countries, the reverse mortgage market continues to be marginal (Fundación de Estudios Financieros 2018). The Financial Studies Foundation suggests a number of reasons for the lack of development of the product in Spain (Fundación de Estudios Financieros 2018): the immaturity of the market, the complexity of the product, the impact of the real estate crisis and the property market, inheritance-related problems, the expense of the transaction and the insurances involved, and the potential claims and risks that might damage the image and reputation of the banks. In addition, although this product has been legislated with a social (Orts Santos 2012) and/or care purpose (Cabrero García 2017), the incorporation of the private market (credit institutions and insurance companies) into its commercialization might compromise this purpose, relegating it to a secondary level and turning the product into a business (Toral Lara 2008).

We have focused our study on Spain for various reasons. First, it has one of the highest old-age-dependency ratios in the EU (Eurostat 2020). Second, there is a high percentage of homeownership among the elderly. The Survey of Household Finances (Banco de España 2014) shows that persons in the 55-64 and 65-74 age groups are those with the highest levels of accumulated wealth, reflected in both the value of the household's real and financial assets and the value of the home, with a lower level of mortgage debt, and with these values being highest in the 65-74 age group (Banco de España 2017b). According to the Spanish National Statistics Institute, across all ages, $76.1 \%$ of homes are owner-occupied, while among people aged 65 or over, the figure is $89.6 \%^{3}$ (Instituto Nacional de Estadística 2019a). However, despite this availability, their use as a source for funding the needs of the ageing population, be these related to health, long-term care or any other type of expenditure, has been minimal. Third, the Spanish administration's public pension scheme is going to suffer pressure due to demographic and economic changes - as are other neighbouring countries-(García Díaz 2019), and equity release schemes, such as reverse mortgages, could be helpful to complement social or private pensions. Fourth, as stated above, there is a strong preference for home ownership, motivated both by market trends and public policy (Pittini et al. 2017), with the country being below the European average as regards alternatives to owner occupation or the private housing market (see Appendix). This scenario leaves Spain in a position of weakness in housing provision in the case of economic crisis (Pareja-Eastaway and Sánchez-Martínez 2017).

Hence, given the high rate of home ownership in Spain, particularly among people aged 65 or over, the level of development of alternatives to owner occupation or the private market compared to the rest of Europe, and the scant presence of the private reverse mortgage market, despite being an effective tool to safeguard assets and services at advanced ages, the aim of the present study is to construct a theoretical model that permits the equity release of residential property via state intervention. In addition, as stated above, this model will also allow public administration to become possible managers of a stock of public

\footnotetext{
2 Law 41/2007, of December 7, modifying Law 2/181 of 25 March, on the regulation of the mortgage market and other rules of the mortgage and financial system, regulating reverse mortgages and long-term care insurance, and establishing certain tax regulations (Boletín Oficial del Estado 2007).

$390.3 \%$ of men and $88.6 \%$ of women.
} 
housing intended for social purposes, provided that the owner of the property-or their heirs, if the borrower dies before repayment is due-decides not to cover the cost of the public loan. Consequently, it would help solve one of the deficiencies detected by the Bank of Spain (López-Rodríguez and Matea 2019): the limited supply of public rental housing. In addition, the study is complemented by an estimation of the total monthly income such older adults would receive, taking into account the revenue obtained from the transaction.

\section{Methodology}

\subsection{Study population and potential beneficiaries}

The demographic data were obtained from the Ongoing Register of Inhabitants provided by the National Statistics Institute, using the figures from the register on 1 January 2018 (Instituto Nacional de Estadística 2019b). The total number of inhabitants was 46,722,980. The population of interest comprises individuals aged between 65 years and the average life expectancy at that age in Spain, which is, for both sexes, 21.27 years (Instituto Nacional de Estadística 2019c). Thus, we selected individuals aged between 65 and 86, obtaining a total of 7,901,425 persons, of whom 3,523,176 are male (44.59\%) and 4,378,249 are female $(55.41 \%)$.

To find the number of potential beneficiary households, we assumed the representative data on the number of owner-occupied homes to be that corresponding to the number of women, for the following reasons: (a) of the persons aged 65 or over, most are married, (b) the matrimonial property regime in this group is mainly community of property, (c) life expectancy of women is higher than that of men, and hence, if they are widowed, the home continues to be their property.

In other words, we assume that the number of potential households that could be beneficiaries of a reverse mortgage is linked to the number of women registered in the population. To this number, we then apply the mean percentage of home ownership (89.6\%).

\subsection{Income of the population aged 65 or over}

The income of individuals aged 65 or over was obtained from the 2018 Living Conditions Survey of the National Statistics Institute (Instituto Nacional de Estadística 2019a). Accordingly, we selected all the households where the head of the household was in that age range. The variable used was the total disposable household income in the year prior to the interview, without including the imputed rent. We used the variable without imputed rent because, according to the National Statistics Institute (Instituto Nacional de Estadística 2019a): "imputed rental is applied to those households that do not pay a complete rent, either because they are resident-owners or because they reside in the dwelling rented at a price below the market price, or because they live there free of charge. The amount imputed is equivalent to the going market price of the rent that would have to be paid for a dwelling similar to that occupied, minus any rent actually paid. The interest on the mortgage granted for the purchase of the main residence is also deducted from the total income of the household." The figure of interest for our study is the real disposable income available to cover expenses related to ageing. The average income calculated is assumed to remain constant for every year. 


\subsection{Property Value}

Property value was obtained from the data provided by Wave 7 of the Survey of Health, Ageing and Retirement in Europe (SHARE) (Bergmann et al. 2019; Börsch-Supan 2019; Börsch-Supan et al. 2013). This survey asks owners how much they consider their home is worth (subjective value). Of the total sample surveyed, 7478 respondents answered this question, of whom 805 lived in Spain. After eliminating missing data, "don't know", "no reply", and extreme cases-considered as property values $\geq 1.000 .000 €$ $\mathrm{y} \leq 30.000$ - we obtained 318 observations.

\subsection{Reverse mortgage calculation}

To calculate the reverse mortgages, we assumed a series of hypotheses that are difficult to find in daily life, which are similar to those used by other authors in a comparable theoretical exercise (Coda Moscarola et al. 2015). First, we assume that the operation will last, at most, from 65 years (youngest profile) to 87 years. This implies that individuals aged 86 (65 plus average life expectancy at 65 years) can obtain income from their main property for a year. Second, we consider various scenarios, which are that $2 \%, 5 \%$ and $8 \%$ of the population aged 65 or over is interested in a reverse mortgage and the public administrations accept the transactions. The percentage of home ownership according to the data available $(89.6 \%)$ is assumed to remain constant. Third, we ignore any questions related to preferences or behaviours. Fourth, we propose different scenarios for the annual interest rate, which are also assumed to be constant over time: $0.5 \%, 3 \%$ y $7 \%$. Fifth, we use the mean appraised valuation of housing in Spain and assume the income is based on $100 \%$ of this appraised value. In addition, we also include another two scenarios with $50 \%$ and $75 \%$ of the appraised value in the Appendix. Sixth, the value of the dwelling is assumed to remain constant across the whole period.

We use the following expression to calculate the monthly income paid to the borrower (1):

$$
\text { Annuity }=\frac{\text { House value }}{\frac{1-\left(1+r^{12}\right)^{-(87 * 12-\text { age*12) }}}{r^{12}}}
$$

where $r^{12}$ is the monthly interest rate applied to the transaction, obtained from annual interest rate $r$, using the following expression:

$$
\mathrm{r}^{12}=(1+\mathrm{r})^{(1 / 12)}-1
$$

Once this monthly income is calculated, it is converted into annual income, calculated at the end of the year, using the following equation:

$$
\text { Annual income }=\text { Income } \cdot \frac{\left(1+r^{12}\right)^{12}-1}{r^{12}}
$$

This gives us the amount to be paid in the first year by the public administration for each age group. 

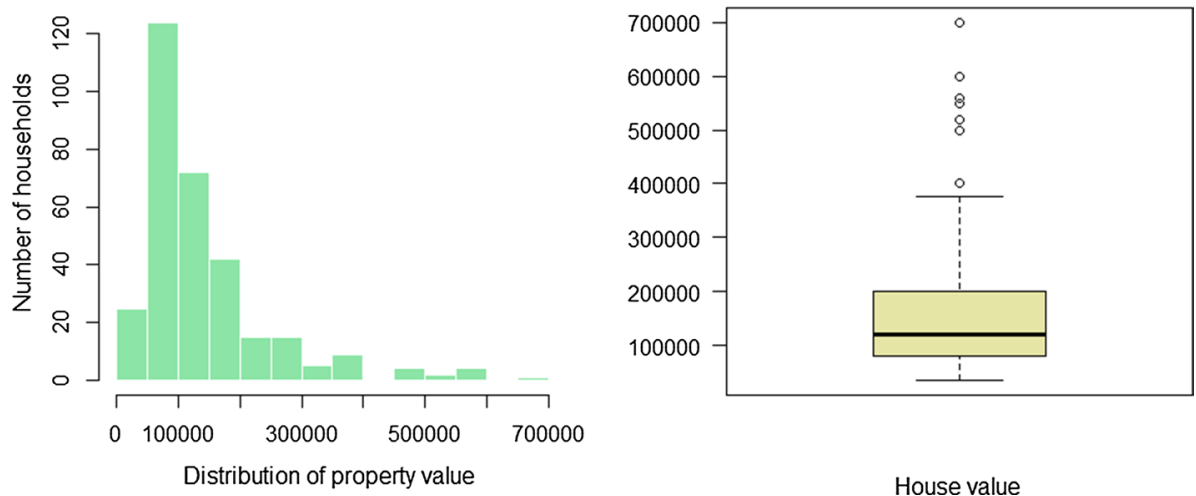

House value

Fig. 2 Distribution of housing value and box plot

Table 1 Total number of homes and total number of potential homes according to occupier age

\begin{tabular}{|c|c|c|}
\hline Occupier age & Total homes & $\begin{array}{l}\text { Potential } \\
\text { homes } \\
(89.6 \%)\end{array}$ \\
\hline 65 & 261,439 & 234,249 \\
\hline 66 & 245,889 & 220,317 \\
\hline 67 & 239,811 & 214,871 \\
\hline 68 & 249,615 & 223,655 \\
\hline 69 & 260,117 & 233,065 \\
\hline 70 & 236,996 & 212,348 \\
\hline 71 & 226,703 & 203,126 \\
\hline 72 & 235,496 & 211,004 \\
\hline 73 & 222,636 & 199,482 \\
\hline 74 & 217,956 & 195,289 \\
\hline 75 & 185,938 & 166,600 \\
\hline 76 & 170,124 & 152,431 \\
\hline 77 & 207,719 & 186,116 \\
\hline 78 & 137,465 & 123,169 \\
\hline 79 & 153,551 & 137,582 \\
\hline 80 & 169,075 & 151,491 \\
\hline 81 & 181,849 & 162,937 \\
\hline 82 & 170,547 & 152,810 \\
\hline 83 & 163,283 & 146,302 \\
\hline 84 & 159,579 & 142,983 \\
\hline 85 & 149,867 & 134,281 \\
\hline 86 & 132,594 & 118,804 \\
\hline
\end{tabular}

The total number of homes is derived from the number of women of each age in the national voters register 
Table 2 Total number of homes according to different scenarios of percentage of households accepting the transaction

\begin{tabular}{llll}
\hline Occupier age & Scenario 1 (2\%) & Scenario 2 $(5 \%)$ & Scenario 3 $(8 \%)$ \\
\hline 65 & 4,685 & 11,712 & 18,740 \\
66 & 4,406 & 11,016 & 17,625 \\
67 & 4,297 & 10,744 & 17,190 \\
68 & 4,473 & 11,183 & 17,892 \\
69 & 4,661 & 11,653 & 18,645 \\
70 & 4,247 & 10,617 & 16,988 \\
71 & 4,063 & 10,156 & 16,250 \\
72 & 4,220 & 10,550 & 16,880 \\
73 & 3,990 & 9,974 & 15,959 \\
74 & 3,906 & 9,764 & 15,623 \\
75 & 3,332 & 8,330 & 13,328 \\
76 & 3,049 & 7,622 & 12,194 \\
77 & 3,722 & 9,306 & 14,889 \\
78 & 2,463 & 6,158 & 9,853 \\
79 & 2,752 & 6,879 & 11,007 \\
80 & 3,030 & 7,575 & 12,119 \\
81 & 3,259 & 8,147 & 13,035 \\
82 & 3,056 & 7,641 & 12,225 \\
83 & 2,926 & 7,315 & 11,704 \\
84 & 2,860 & 7,149 & 11,439 \\
85 & 2,686 & 6,714 & 10,742 \\
86 & 2,376 & 5,940 & 9,504 \\
\hline
\end{tabular}

\section{Results}

The study population comprises $7,901,425$ people, of whom $3,523,176$ are male $(44.59 \%)$ and 4,378,249 are female (55.41\%). Considering the assumptions described in the methodology section, the potential number of households that would take out a reverse mortgage is $3,922,911$. The mean subjective value of the homes is $151,358.50 €(\mathrm{SD}=113,012.50 €)$. Figure 2 shows the distribution of the value of the housing and its corresponding box and whiskers plot.

Table 1 shows the total number of homes and the total number of potential homes depending on the age of the occupier. The declining trend in the total number of homes is explained by the fact that as age increases, the likelihood of surviving is lower. Table 2 shows the number of properties used to make the calculations for each of the scenarios proposed, according to occupier age. Table 3 shows the monthly income obtained by the borrower for each of the scenarios according to the interest rates. Table 4 shows the monthly outlay to be made by the public administration according to different scenarios of percentage of households interested in home equity release for each age group. Table 5 shows the accumulated investment as of the end of the year in the case of granting all the reverse mortgages for all the ages in each of the scenarios considered. In the "Appendix", Tables 7, 8, 9, 10, 11, 12, 13, 14 show the same calculations provided in Tables 2, 3, 4, 5 but considering another two scenarios at $50 \%$ and $75 \%$ of the appraised value of the property. The results reveal that in the most cautious scenario 
Table 3 Monthly income received by the borrower as a result of the transaction (in euros)

\begin{tabular}{|c|c|c|c|}
\hline \multirow[t]{2}{*}{ Age } & \multicolumn{3}{|c|}{ Annual interest rate } \\
\hline & $0.50 \%$ & $3.00 \%$ & $7.00 \%$ \\
\hline 65 & 605.48 & 780.77 & 1105.28 \\
\hline 66 & 632.76 & 807.20 & 1128.30 \\
\hline 67 & 662.78 & 836.37 & 1154.02 \\
\hline 68 & 695.95 & 868.70 & 1182.88 \\
\hline 69 & 732.81 & 904.72 & 1215.39 \\
\hline 70 & 774.01 & 945.08 & 1252.23 \\
\hline 71 & 820.37 & 990.60 & 1294.19 \\
\hline 72 & 872.91 & 1042.31 & 1342.32 \\
\hline 73 & 932.96 & 1101.54 & 1397.95 \\
\hline 74 & 1002.25 & 1170.01 & 1462.82 \\
\hline 75 & 1083.09 & 1250.05 & 1539.25 \\
\hline 76 & 1178.64 & 1344.81 & 1630.39 \\
\hline 77 & 1293.31 & 1458.70 & 1740.67 \\
\hline 78 & 1433.46 & 1598.11 & 1876.49 \\
\hline 79 & 1608.65 & 1772.59 & 2047.42 \\
\hline 80 & 1833.91 & 1997.19 & 2268.53 \\
\hline 81 & 2134.26 & 2296.95 & 2564.91 \\
\hline 82 & 2554.76 & 2716.99 & 2981.75 \\
\hline 83 & 3185.52 & 3347.51 & 3609.39 \\
\hline 84 & 4236.82 & 4398.99 & 4658.64 \\
\hline 85 & 6339.43 & 6502.86 & 6761.97 \\
\hline 86 & $12,647.32$ & $12,816.32$ & $13,081.56$ \\
\hline
\end{tabular}

( $2 \%$ of households enter into the agreement and the interest rate is $0.50 \%$ until the end of life) homeowners would receive a monthly income of between $605 €$ and $12,647 €$, depending on their age, and the state would have to contribute 1705 million euros in the first year. In the least cautious scenario ( $8 \%$ of households take out a reverse mortgage with a $7 \%$ interest rate until the end of life), homeowners would receive a monthly payment of between $1105 €$ and $13,082 €$ and the state would have to pay 8810 million euros. Considering a reverse mortgage over $50 \%$ of the appraised value at the most cautious scenario, homeowners will receive between $303 €$ and $6324 €$ monthly income and the state would have to contribute 852 million euros in the first year.

Finally, Fig. 3 shows the distribution of total disposable household income in the year prior to the interview with imputed rental and its corresponding box and whiskers plot. The average total annual disposable household income is $24,934.28 €(\mathrm{SD}=18,517.81 €)$. Table 6 shows the calculation of the total disposable income if the income form the reverse mortgage is included, for each age group, It is worth noting that as age increases, this payment is significantly higher, because, after the age of 86 , the public administration would become the owner of the borrower's home. Taking all the age groups into account, household incomes would increase by an average of $25,838 €$ per year $(7282 €-152,115 €)$ with an annual interest rate of $0.5 \%, 28,171 €$ per year with an interest rate of $3 \%(9,497 €$ to $155,899 €)$ and $32,243 €$ per year with an interest rate of $7 \%(13,684 €$ to $161,954 €)$. 


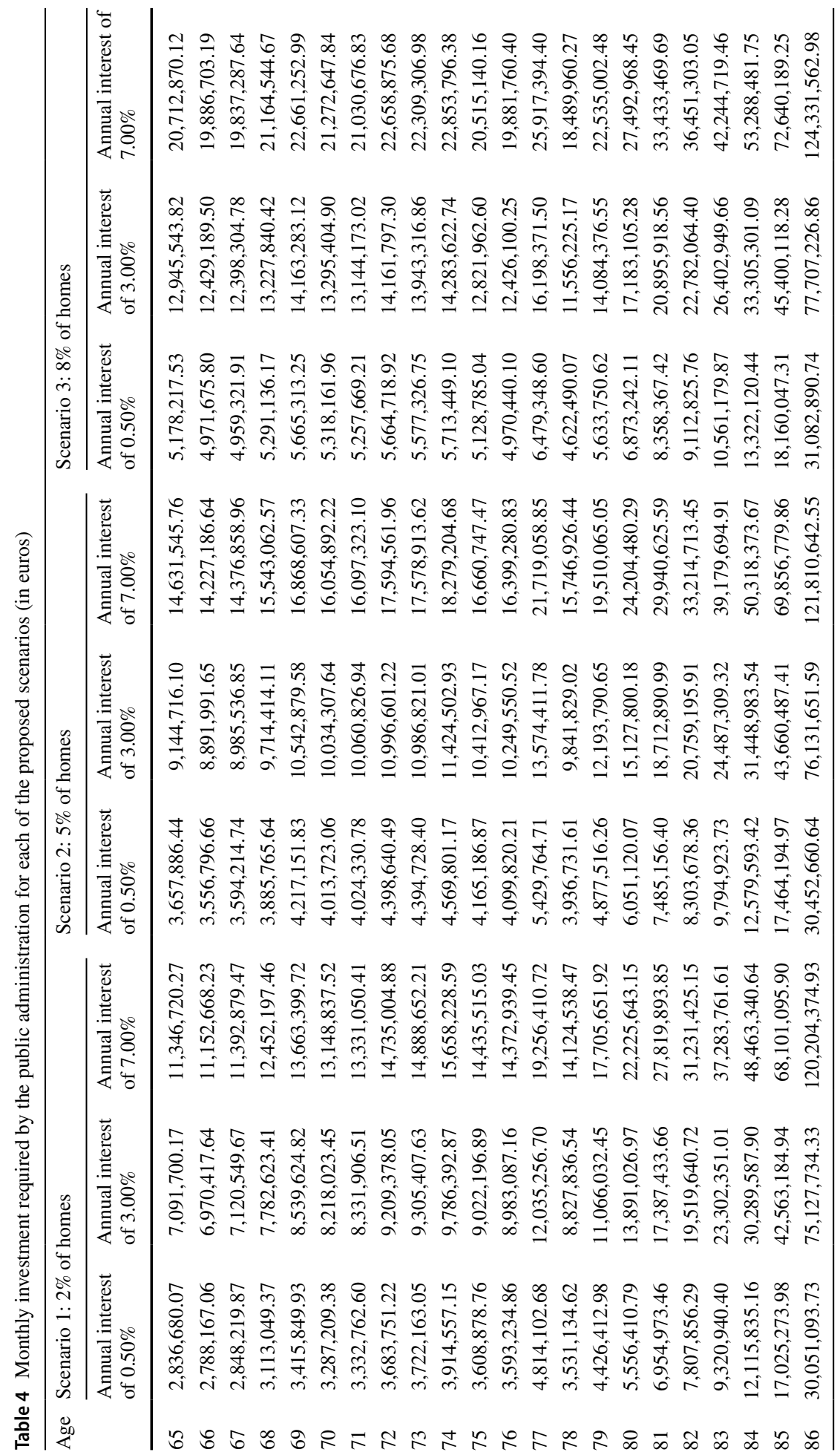


Table 5 Accumulated investment by the State at the end of the first year (in euros)

\begin{tabular}{llr}
\hline Scenario 1: 2\% of homes & Annual interest of 0.50\% & $1,704,877,263.76$ \\
& Annual interest of 3.00\% & $4,310,615,944.86$ \\
& Annual interest of 7.00\% & $7,019,557,042.11$ \\
Scenario 2: 5\% of homes & Annual interest of 0.50\% & $1,863,698,018.17$ \\
& Annual interest of 3.00\% & $4,712,178,738.20$ \\
Scenario 3: 8\% of homes & Annual interest of 7.00\% & $7,673,475,871.79$ \\
& Annual interest of 0.50\% & $2,139,717,656.50$ \\
& Annual interest of 3.00\% & $5,410,067,483.24$ \\
& Annual interest of 7.00\% & $8,809,942,195.29$ \\
\hline
\end{tabular}

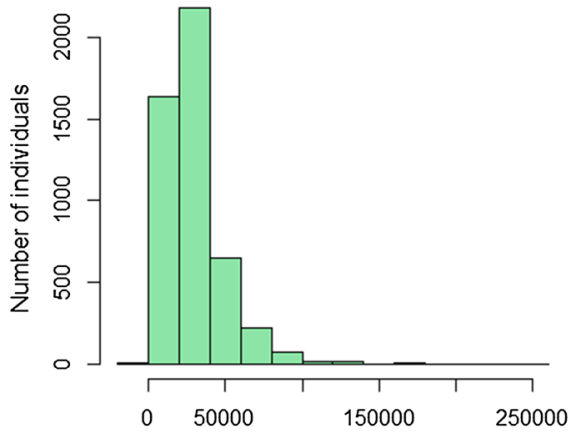

Distribution of total household disposable income

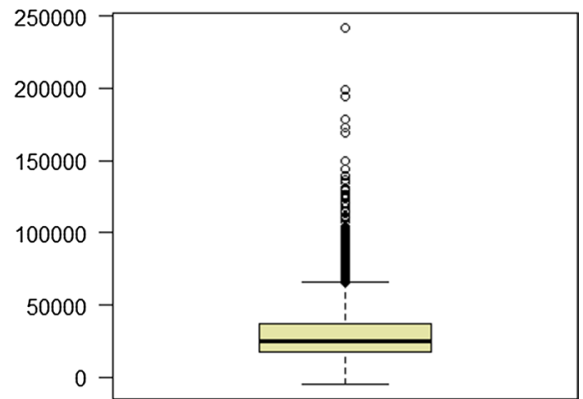

Total household disposable income

Fig. 3 Distribution of total disposable income of households in the year prior to the interview with the imputed rent and the box plot

If we assume the most cautious scenario (only $2 \%$ of households take out a reverse mortgage), and only taking into account the cohort considered in this study, within approximately 22 years, the public administration would acquire 78,458 dwellings for an investment of 540 million euros per year, in current terms, across the duration of the initiative. ${ }^{4}$

\section{Discussion}

This work focuses on the reverse mortgage as a financial tool to the interest of individuals aged 65 years or over in Spain. The reverse mortgage market is underdeveloped in Spain, despite being a useful mechanism for generating income to enhance the standard of living of older adults and dependent persons, and to reduce poverty (Coda Moscarola et al. 2015). The public administration could use equity release to provide this older population with income, while also obtaining homes with which to increase public housing stocks. To the best of our knowledge, our proposal of the administration

\footnotetext{
${ }^{4}$ This figure corresponds to 78,458 homes at $151,358 € /$ home, divided by 22 years.
} 
Table 6 Calculation of the mean total disposable income and the income received from the reverse mortgage (in euros)

\begin{tabular}{|c|c|c|c|}
\hline Age & $\begin{array}{l}\text { Annual interest of } \\
0.50 \%\end{array}$ & $\begin{array}{l}\text { Annual interest of } \\
3.00 \%\end{array}$ & $\begin{array}{l}\text { Annual } \\
\text { interest of } \\
7.00 \%\end{array}$ \\
\hline 65 & $32,216.71$ & $34,431 ., 63$ & $38,617.96$ \\
\hline 66 & $32,544.83$ & $34,753.17$ & $38,903.00$ \\
\hline 67 & $32,905.80$ & $35,107.95$ & $39,221.45$ \\
\hline 68 & $33,304.79$ & $35,501.20$ & $39,578.67$ \\
\hline 69 & $33,748.15$ & $35,939.36$ & $39,981.22$ \\
\hline 70 & $34,243.70$ & $36,430.34$ & $40,437.20$ \\
\hline 71 & $34,801.24$ & $36,984.06$ & $40,956,73$ \\
\hline 72 & $35,433,17$ & $37,613,06$ & $41,552.63$ \\
\hline 73 & $36,155.41$ & $38,333.49$ & $42,241.36$ \\
\hline 74 & $36,988.81$ & $39,166.45$ & $43,044.45$ \\
\hline 75 & $37,961.17$ & $40,140.07$ & $43,990.62$ \\
\hline 76 & $39,110.37$ & $41,292.72$ & $45,118.98$ \\
\hline 77 & $40,489.48$ & $42,678.11$ & $46,484.33$ \\
\hline 78 & $42,175.13$ & $44,373.84$ & $48,165.76$ \\
\hline 79 & $44,282.27$ & $46,496.27$ & $50,281.95$ \\
\hline 80 & $46,991.53$ & $49,228.28$ & $53,019.34$ \\
\hline 81 & $50,603.99$ & $52,874.68$ & $56,688.66$ \\
\hline 82 & $55,661.57$ & $57,984.10$ & $61,849.21$ \\
\hline 83 & $63,248.08$ & $65,653.81$ & $69,619.56$ \\
\hline 84 & $75,892.48$ & $78,444.11$ & $82,609.69$ \\
\hline 85 & $101,181.60$ & $104,035.87$ & $108,649.42$ \\
\hline 86 & $177,049.57$ & $180,833.54$ & $186,887.88$ \\
\hline
\end{tabular}

as the lending entity has not previously been analysed, as the private market has always been considered the appropriate operator. In the United States, for example, there exists a federal programme called Home Equity Conversion Mortgage (HECM), but the only function of this public initiative is to establish the amount to be received and the costs of the transaction and to guarantee that both parties meet their commitments (Blay Berrueta 2007). Our contribution could constitute another source of income for the elderly, and our idea should not be taken as a substitute for public pensions. If the public administrations consider this model, they will need to elaborate specific regulation-complementing Law 41/2007 or enacting other new regulation. In our view, the public administration may become the owner of the property when the heirs affirm they will not pay back the loan. Otherwise, the public administration could provide the heirs with payment facilities to recover the investment. The income perceived by the beneficiaries could be used on any social purpose, due to the social nature of the product (SimónMoreno 2019). Other dwellings than primary residences could be mortgaged, but the priority should be people who wish to mortgage their main residence and those who are experiencing severe financial problems. Each request should be evaluated in order to establish an order of access to the programme. The tax benefits, some of which are included in Law 24/2007, should be maintained in order to incentivize the programme but they should be conditioned-e.g. attending to the characteristics of the beneficiaries, such as people suffering unexpected health and long-term care shocks. 
Our findings show that in 22 years the public administration would obtain 78,458 public housing units in exchange for an investment of 540 million euros per year at current prices. As a result, these households would increase their total disposable income by a minimum of 7282 euros per year, taking into account the time value of money. This investment represents a significant expenditure for the public administration and thus it is key to find a budgetary solution that ensures the correct functioning of the initiative. In 2019, the level of public spending in Spain was $41.9 \%$ of the Gross Domestic Product (Eurostat 2019a), four points below the average of the European Union. According to Eurostat, Spain's GDP in 2018-2019 was approximately 1.2 billion euros (Eurostat 2019a), which means the level of annual government spending is around 500,000 million euros. The least cautious scenario analysed in this work assumes that $8 \%$ of households take out a reverse mortgage at an interest rate of $7 \%$, which would generate, in the first year, a cost to the public administration of 8.8 thousand million euros, which represents $1.8 \%$ of the 500,000 million euros of total public spending. As a comparison, Spain spent $4.00 \%$ of GDP on education in 2018 (Eurostat 2019b), 0.70\% of GDP on long-term care in 2018 (OECD 2019) and our initiative would account for an expenditure of $0.73 \%$ of GDP- $-0.86 \%$ of GDP considering the economic outlook under the double-hit scenario of the COVID-19 public health crisis (OECD 2020). On the other hand, if the level of public spending in Spain were equal to the average of the EU-28, that is, 45.8\% of GDP (Eurostat 2019a), the public administration would have 47.000 million euros extra available per year. This would then represent barely $19 \%$ of the 47.000 million euro increase in expenditure.

In comparison with other budget items, such as education, the level of yearly investment in home equity release would not be excessively high. If, in addition, public spending approached the European average, Spain would free up an amount that could cover the costs of the least cautious of the scenarios proposed herein, and this without taking other options into account. For example, in the medium or long term, the public administration would have another source of income through placing the housing obtained on the market. This involves applying the individual or family economic life-cycle model (Browning and Crossley 2001), but with one important difference: the State is the agent that would take decisions on consumption, saving and investment, taking the time horizon into account. In addition, the investment could be recovered through the payment of debt by heirs or because the borrower decides to sell the home and pay off the mortgage. Neither do we consider here the possibility of the transaction being framed in other terms, such as, for example, the income being converted into the provision of in-kind long-term care services or to cover the cost of a place in a care home.

Finally, it should be noted that our results have substantial limitations. The aim of this work is not so much to present a solid economic and financial model to solve the problem of lack of liquidity in old age and public housing, as to present a highly simplified theoretical model, which, if suitably calibrated and adjusted, might help enrich the body of knowledge on alternative funding for the ageing population, with an interesting counterpart contribution for the public administration. These results should thus be taken with caution. As social scientists, we are committed to solving present and future social problems, or, to devising and exploring possible solutions to such issues. Consequently, we now detail the theoretical and practical limitations of our proposal, which should serve as motivation for future work. First, assuming the number of existing homes among individuals aged 65 or over should be equal to the number of women in the population is an inaccurate supposition, although we consider it to be approximate to the actual figure for the reasons previously explained. Second, it cannot be assumed that mean total disposable income of incomes will remain constant over such a long period of time. In addition, the use of the arithmetical mean in an asymmetric distribution is not a good approximation to the situation of most households. Third, the value of housing fluctuates over time, and thus future 
works should include projections of its value. Fourth, we have assumed the length of the mortgage to be 22 years (from age 65 to the mean life expectancy at that age), while these types of contracts are typically signed for 10 or 20 years (Blay Berrueta 2007). Fifth, the scenarios for interest rates may be unrealistic and future analyses should better compute their evolution, although we have included low interest rates, and ones close to zero, as well as higher rates. Sixth, we assume that the home ownership rate will remain constant over time while it does, in fact, vary. The current data suggest that the home ownership rate among younger adults (aged 16-29) is falling to levels below that of 2004 (Instituto Nacional de Estadística 2019a). Evidence has shown that, through the Global Financial Crisis, young consumers' willingness to invest in property and the willingness of banks to lend them money deteriorated (Lennartz et al. 2016). These circumstances could compromise the model in the future. In addition, as the programme would be publicly funded, young people might complain about the use of public resources for this purpose. Hence, it is important to show that their age group would be one those most benefited by the programme, because the houses would be included as public housing, and the programme could help secure accessibility to decent housing for younger adults (Lennartz et al. 2016). Seventh, none of the risks involved in the transaction have been taken into account (e.g. longevity). Regarding the risk of under-maintaining the house because the government will be the next owner could be diminished by including a clause in the contract about the maintenance of the house (e.g. mandatory assurance). In future research, these and other risks should be considered. Finally, the mortgage is granted for $100 \%$ of the appraisal valuation, when the value could actually be lower, since the power to negotiate is, in this case, in the hands of the public administration. To offer a complementary view, we have included estimations in the Appendix with $50 \%$ and $75 \%$ of the appraisal valuation.

\section{Conclusions}

The reverse mortgage, a form of asset-based welfare is an interesting financial tool to mitigate the economic problems of ageing. However, its use is not widespread among older persons. The literature has highlighted various concerns that have led private lenders and borrowers to shy away from its application-e.g. bequest motives, risks, reputation. Our work provides a different approach in the literature of equity release schemes, aiming to fill the gap in knowledge on state-based reverse mortgages. If public administrations act as lenders in this transaction, they could obtain homes to include in the public housing stock, thereby enhancing it. Our case study is Spain, a country with high old-age-dependency, a high-rate of homeownership, a public pension system that will be under pressure, and an undeveloped public housing stock. Our results showed that in a scenario with $8 \%$ of potential households opting for equity release-313,833 homes-and a constant interest rate of $7 \%$, the level of expenditure for the public administration for the first year would be 8,810 million euros, equivalent to approximately $0.73 \%$ of GDP. These households would receive an extra annual income of $32,243 €$ in mean terms, taking into account all the age groups under analysis. Despite the various limitations of this study, these results show that our proposal is feasible, and there should be no problems to fund this model. This will be even truer if Spain brings its level of public spending equal to the European average. Our work may help advance the creation of alternative methods to fund the economic and social problems of population ageing. 
Acknowledgements The authors would like to thank two reviewers and editor for their suggestions on earlier versions of this paper. The authors thank all colleagues which have invest their time commenting on earlier versions of this work.

Funding This work has been funded by the Universidad de Castilla-La Mancha (Grant No. GRIN-27194) and by the Spanish State Program of R+D+I ECO 2017-83771-C3-1-R.

\section{Compliance with ethical standards}

Conflict of interest Francisco Escribano-Sotos has received research Grants from the Universidad de Castilla-La Mancha.

\section{Appendix}

\section{Housing situation in Europe and Spain}

For our analysis, we used the report elaborated by Housing Europe, which shows the state of housing in the EU in 2017 (Pittini et al. 2017). The profiles in the housing sector vary widely across the European Union Member States: home ownership, private rental, social rental, public rental, housing cooperatives, tenant reduced rental and other alternatives not included in these groups. The following considerations were made: (i) we did not consider reduced rent or rent-free dwellings, either social or public, unless the report considered them (for example, for Italy, the report considers that $3.7 \%$ of tenants that pay a reduced rent for their homes, of which $75 \%$ are managed by public housing companies, live in social rental dwellings), (ii) we put social rental, public rental and cooperatives in the same group since we considered them alternatives to the private market or home ownership, (iii) the report provides the percentage of public housing for some countries, but does not include it in the analysis (for example, it states that in Malta it represents around $5.5 \%$ and so this percentage was always considered to be $>1 \%$ ).

Across all countries, the most common type of housing is home ownership. In mean terms, $71.36 \%$ of countries present this accommodation type. The lowest percentage is found in Sweden (39\%) and the highest in Romania (98.2\%). Spain is situated between 4 and 5 percentage points above the mean in Europe, depending on whether we use the data from the EU report (77.1\%) or the more recent Fig. (76.1\%) from the Spanish National Statistics Institute (Instituto Nacional de Estadística 2019a). The next most common option is private rent, with a mean percentage of $15.93 \%$, followed by alternatives to the private market $(9.64 \%)$ and other varieties $(<1 \%)$. The percentage of use of alternatives to the private market in Spain is $2.50 \%$, seven percentage points below the mean. The country with the highest percentage of alternatives to the private market is Sweden, with $42 \%$, while in other countries, such as Greece, Latvia and Luxembourg, this alternative is totally undeveloped. Figure 4 shows the percentages of dwellings under alternative regimes to the private market and home ownership. 


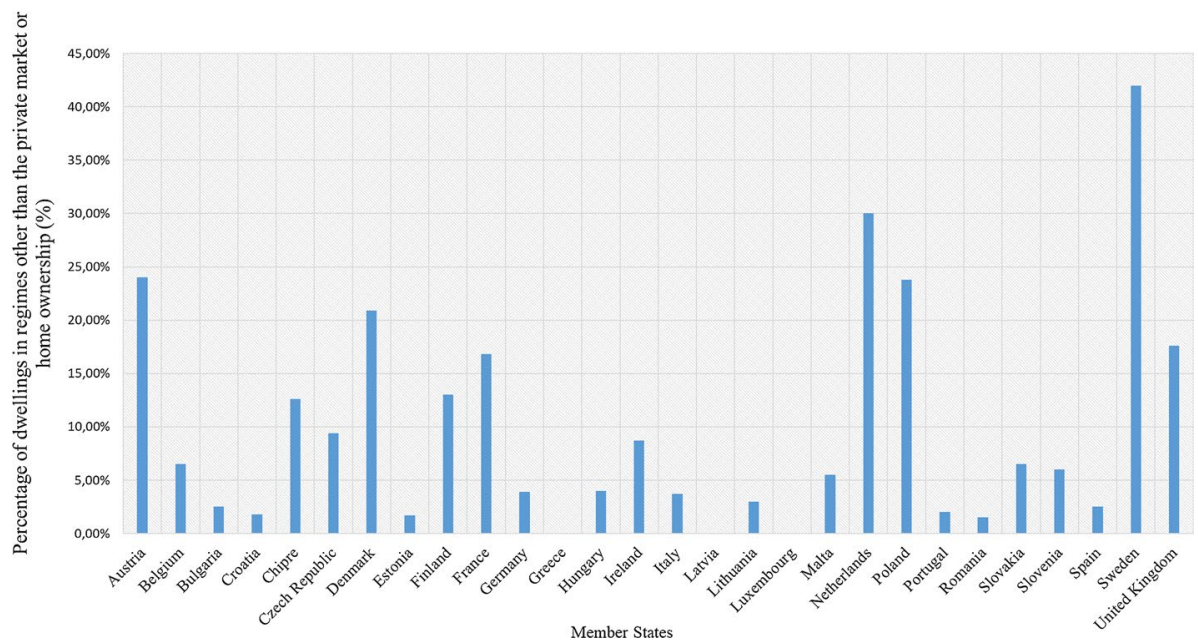

Fig. 4 Percentage of dwellings in regimes other than the private market or home ownership

Estimating monthly income received by the borrower (in euros) and monthly investment required by the public administration for each of the proposed scenarios considering $50 \%$ and $75 \%$ of appraised value

See Tables 7, 8, 9, 10, 11, 12, 13, 14.

Table 7 Monthly income received by the borrower as a result of the transaction (in euros) at $50 \%$ of appraised value

\begin{tabular}{|c|c|c|c|}
\hline \multirow[t]{2}{*}{ Age } & \multicolumn{3}{|c|}{ Annual interest rate } \\
\hline & $0.50 \%$ & $3.00 \%$ & $7.00 \%$ \\
\hline 65 & 302.74 & 390.38 & 552.64 \\
\hline 66 & 316.38 & 403.60 & 564.15 \\
\hline 67 & 331.39 & 418.18 & 577.01 \\
\hline 68 & 347.97 & 434.35 & 591.44 \\
\hline 69 & 366.41 & 452.36 & 607.70 \\
\hline 70 & 387.01 & 472.54 & 626.11 \\
\hline 71 & 410.18 & 495.30 & 647.09 \\
\hline 72 & 436.45 & 521.16 & 671.16 \\
\hline 73 & 466.48 & 550.77 & 698.98 \\
\hline 74 & 501.12 & 585.01 & 731.41 \\
\hline 75 & 541.55 & 625.03 & 769.62 \\
\hline 76 & 589.32 & 672.41 & 815.19 \\
\hline 77 & 646.65 & 729.35 & 870.34 \\
\hline 78 & 716.73 & 799.05 & 938.24 \\
\hline 79 & 804.32 & 886.29 & 1023.71 \\
\hline 80 & 916.95 & 998.59 & 1134.26 \\
\hline 81 & 1067.13 & 1148.48 & 1282.46 \\
\hline
\end{tabular}


Table 7 (continued)

Table 8 Monthly income received by the borrower as a result of the transaction (in euros) at $75 \%$ of appraised value

\begin{tabular}{llll}
\hline Age & \multicolumn{2}{l}{ Annual interest rate } & \\
\cline { 2 - 4 } & $0.50 \%$ & $3.00 \%$ & $7.00 \%$ \\
\hline 82 & 1277.38 & 1358.50 & 1490.87 \\
83 & 1592.76 & 1673.76 & 1804.69 \\
84 & 2118.41 & 2199.49 & 2329.32 \\
85 & 3169.71 & 3251.43 & 3380.98 \\
86 & 6323.66 & 6408.16 & 6540.78 \\
\hline
\end{tabular}

\begin{tabular}{|c|c|c|c|}
\hline \multirow[t]{2}{*}{ Age } & \multicolumn{3}{|c|}{ Annual interest rate } \\
\hline & $0.50 \%$ & $3.00 \%$ & $7.00 \%$ \\
\hline 65 & 454.11 & 585.58 & 828.96 \\
\hline 66 & 474.57 & 605.40 & 846.23 \\
\hline 67 & 497.08 & 627.28 & 865.52 \\
\hline 68 & 521.96 & 651.52 & 887.16 \\
\hline 69 & 549.61 & 678.54 & 911.55 \\
\hline 70 & 580.51 & 708.81 & 939.17 \\
\hline 71 & 615.28 & 742.95 & 970.64 \\
\hline 72 & 654.68 & 781.73 & 1006.74 \\
\hline 73 & 699.72 & 826.15 & 1048.47 \\
\hline 74 & 751.69 & 877.51 & 1097.12 \\
\hline 75 & 812.32 & 937.54 & 1154.44 \\
\hline 76 & 883.98 & 1008.61 & 1222.79 \\
\hline 77 & 969.98 & 1094.03 & 1305.50 \\
\hline 78 & 1075.09 & 1198.58 & 1407.37 \\
\hline 79 & 1206.49 & 1329.44 & 1535.57 \\
\hline 80 & 1375.43 & 1497.89 & 1701.40 \\
\hline 81 & 1600.69 & 1722.71 & 1923.68 \\
\hline 82 & 1916.07 & 2037.74 & 2236.31 \\
\hline 83 & 2389.14 & 2510.63 & 2707.04 \\
\hline 84 & 3177.61 & 3299.24 & 3493.98 \\
\hline 85 & 4754.57 & 4877.15 & 5071.47 \\
\hline 86 & 9485.49 & 9612.24 & 9811.17 \\
\hline
\end{tabular}




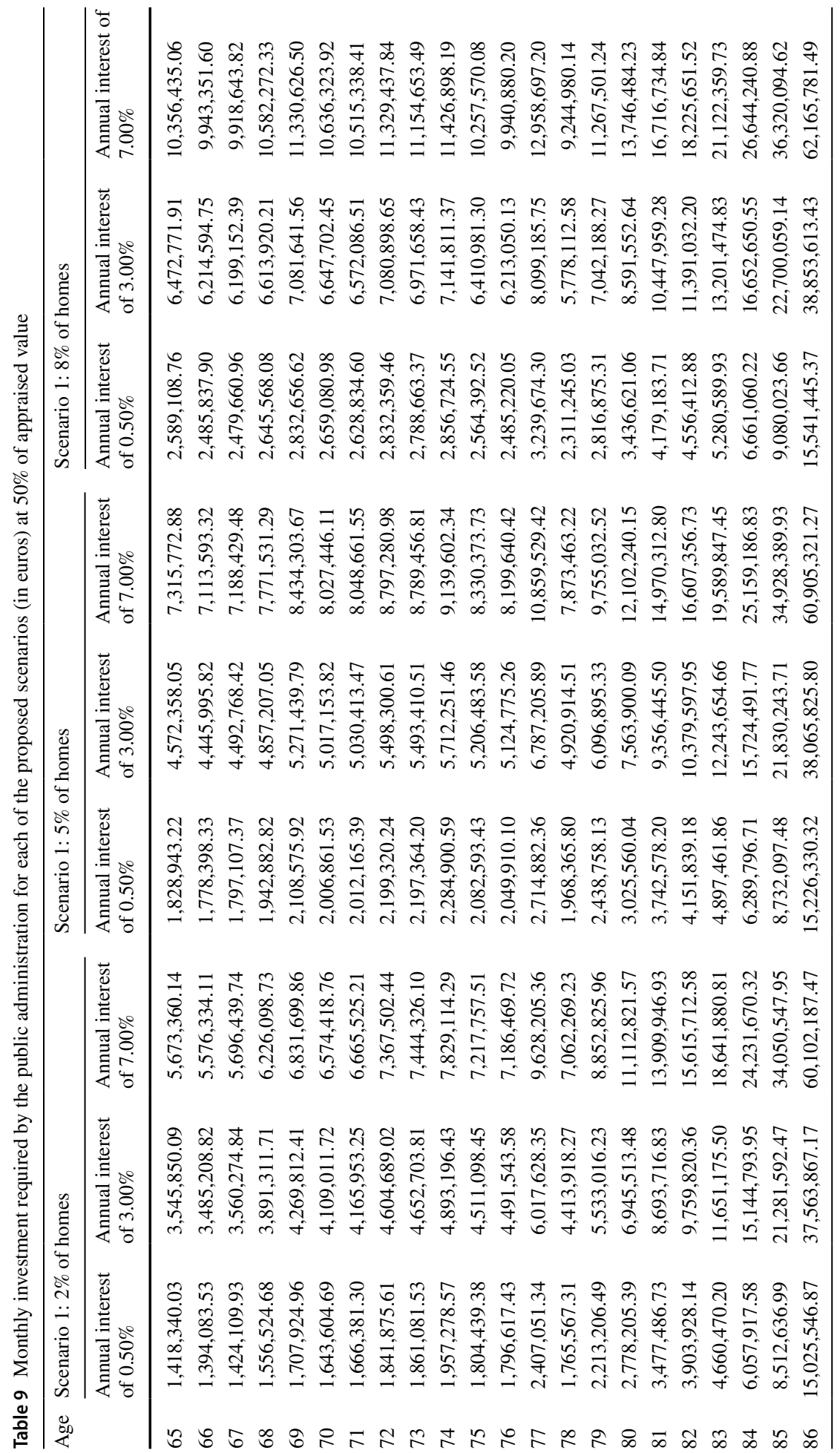




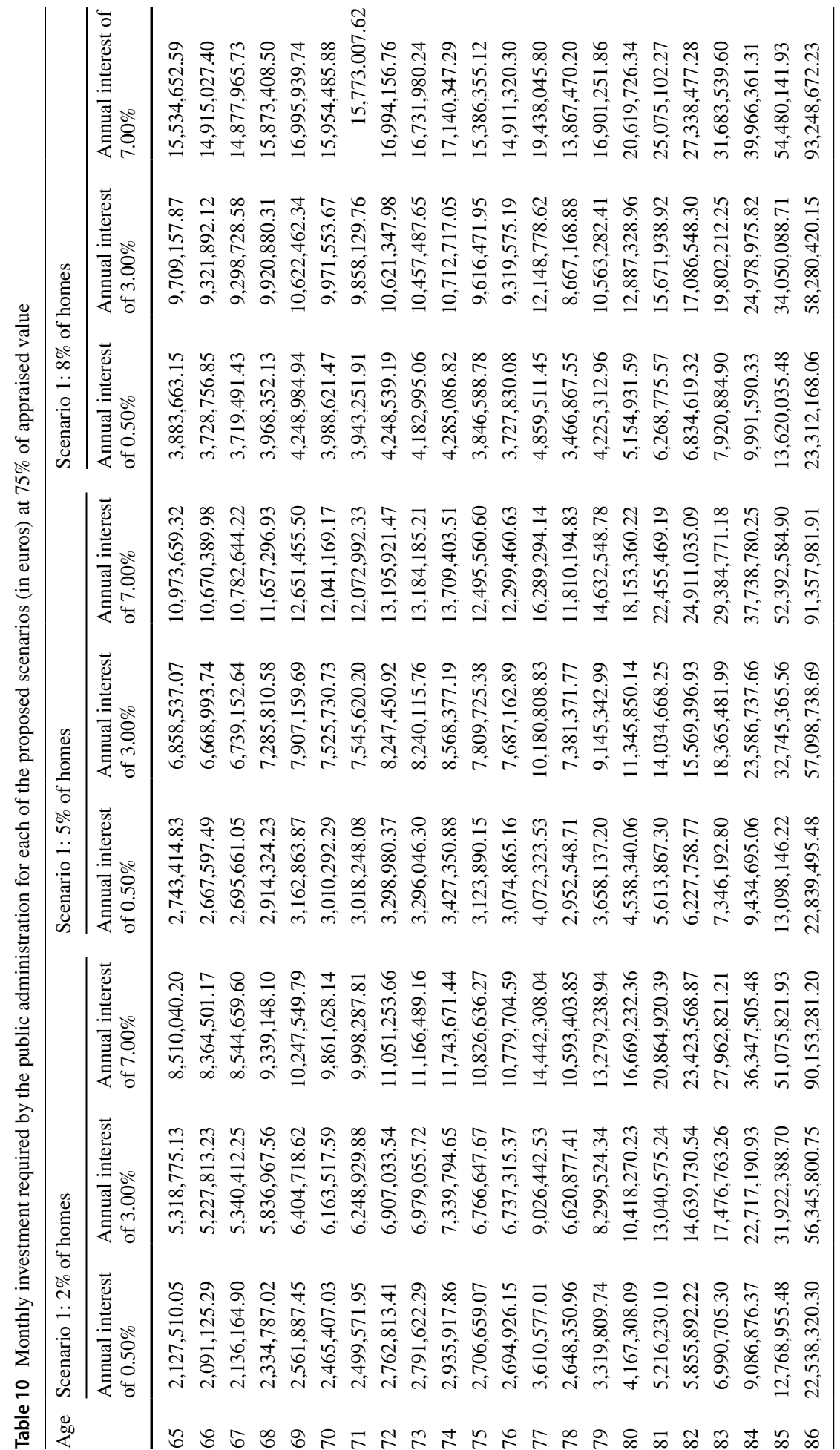


Table 11 Accumulated investment by the State at the end of the first year (in euros) at 50\% of appraised value

Scenario 1: $2 \%$ of homes

Scenario 2: $5 \%$ of homes

Scenario 3: $8 \%$ of homes

Annual interest of $0.50 \%$

Annual interest of 3.00\%

Annual interest of $7.00 \%$

Annual interest of $0.50 \%$

Annual interest of 3.00\%

Annual interest of $7.00 \%$

Annual interest of $0.50 \%$

Annual interest of 3.00\%

Annual interest of $7.00 \%$
$852,438,631.88$

$2,155,307,972.43$

$3,509,778,521.06$

$931,849,009.09$

$2,356,089,369.10$

$3,836,737,935.89$

$1,069,858,828.25$

$2,705,033,741.62$

$4,404,971,097.65$

Table 12 Accumulated investment by the State at the end of the first year (in euros) at $75 \%$ of appraised value

Scenario $1: 2 \%$ of homes

Scenario 2: $5 \%$ of homes

Scenario 3: $8 \%$ of homes
Annual interest of $0.50 \%$

Annual interest of $3.00 \%$

Annual interest of $7.00 \%$

Annual interest of $0.50 \%$

Annual interest of $3.00 \%$

Annual interest of $7.00 \%$

Annual interest of $0.50 \%$

Annual interest of 3.00\%

Annual interest of $7.00 \%$
$1,278,657,947.82$

$3,232,961,958.64$

$5,264,667,781.59$

$1,397,773,513.63$

$3,534,134,053.65$

$5,755,106,903.84$

$1,604,788,242.38$

$4,057,550,612.43$

$6,607,456,646.47$ 
Table 13 Calculation of the mean total disposable income and the income received from the reverse mortgage (in euros) at $50 \%$ of appraised value

\begin{tabular}{|c|c|c|c|}
\hline Age & $\begin{array}{l}\text { Annual interest of } \\
0.50 \%\end{array}$ & $\begin{array}{l}\text { Annual interest of } \\
3.00 \%\end{array}$ & $\begin{array}{l}\text { Annual inter- } \\
\text { est of } 7.00 \%\end{array}$ \\
\hline 65 & $28,575.50$ & $29,682.96$ & $31,776.12$ \\
\hline 66 & $28,739.56$ & $29,843.73$ & $31,918.64$ \\
\hline 67 & $28,920.04$ & $30,021.11$ & $32,077.87$ \\
\hline 68 & $29,119.53$ & $30,217.74$ & $32,256.48$ \\
\hline 69 & $29,341.21$ & $30,436.82$ & $32,457.75$ \\
\hline 70 & $29,588.99$ & $30,682.31$ & $32,685.74$ \\
\hline 71 & $29,867.76$ & $30,959.17$ & $32,945.51$ \\
\hline 72 & $30,183.72$ & $31,273.67$ & $33,243.45$ \\
\hline 73 & $30,544.84$ & $31,633.89$ & $33,587.82$ \\
\hline 74 & $30,961.54$ & $32,050.37$ & $33,989.37$ \\
\hline 75 & $31,447.72$ & $32,537.18$ & $34,462.45$ \\
\hline 76 & $32,022.33$ & $33,113.50$ & $35,026.63$ \\
\hline 77 & $32,711.88$ & $33,806.20$ & $35,709.30$ \\
\hline 78 & $33,554.70$ & $34,654.06$ & $36,550.02$ \\
\hline 79 & $34,608.27$ & $35,715.27$ & $37,608.11$ \\
\hline 80 & $35,962.91$ & $37,081.28$ & $38,976.81$ \\
\hline 81 & $37,769.14$ & $38,904.48$ & $40,811.47$ \\
\hline 82 & $40,297.92$ & $41,459.19$ & $43,391.74$ \\
\hline 83 & $44,091.18$ & $45,294.05$ & $47,276.92$ \\
\hline 84 & $50,413.38$ & $51,689.19$ & $53,771.98$ \\
\hline 85 & $63,057.94$ & $64,485.08$ & $66,791.85$ \\
\hline 86 & $100,991.93$ & $102,883.91$ & $105,911.08$ \\
\hline
\end{tabular}


Table 14 Calculation of the mean total disposable income and the income received from the reverse mortgage (in euros) at $75 \%$ of appraised value

\begin{tabular}{llll}
\hline Age & $\begin{array}{l}\text { Annual interest of } \\
0.50 \%\end{array}$ & $\begin{array}{l}\text { Annual interest of } \\
3.00 \%\end{array}$ & $\begin{array}{l}\text { Annual inter- } \\
\text { est of } 7.00 \%\end{array}$ \\
\hline 65 & $30,396.10$ & $32,057.29$ & $35,197.04$ \\
66 & $30,642.19$ & $32,298.45$ & $35,410.82$ \\
67 & $30,912.92$ & $32,564.53$ & $35,649.66$ \\
68 & $31,212.16$ & $32,859.47$ & $35,917.57$ \\
69 & $31,544.68$ & $33,188.09$ & $36,219.49$ \\
70 & $31,916.35$ & $33,556.33$ & $36,561.47$ \\
71 & $32,334.50$ & $33,971.61$ & $36,951.12$ \\
72 & $32,808.44$ & $34,443.37$ & $37,398.04$ \\
73 & $33,350.13$ & $34,983.69$ & $37,914.59$ \\
74 & $33,975.18$ & $35,608.41$ & $38,516.91$ \\
75 & $34,704.44$ & $36,338.62$ & $39,226.53$ \\
76 & $35,566.35$ & $37,203.11$ & $40,072.81$ \\
77 & $36,600.68$ & $38,242.16$ & $41,096.81$ \\
78 & $37,864.92$ & $39,513.95$ & $42,357.89$ \\
79 & $39,445.27$ & $41,105.77$ & $43,945.03$ \\
80 & $41,477.22$ & $43,154.78$ & $45,998.07$ \\
81 & $44,186.57$ & $45,889.58$ & $48,750.06$ \\
82 & $47,979.74$ & $49,721.65$ & $52,620.48$ \\
83 & $53,669.63$ & $55,473.93$ & $58,448.24$ \\
84 & $63,152.93$ & $65,066.65$ & $68,190.84$ \\
85 & $82,119.77$ & $84,260.47$ & $87,720.64$ \\
86 & $139,020.75$ & $141,858.72$ & $146,399.48$ \\
\hline
\end{tabular}

\section{References}

ASIC. (2018). Review of reverse mortgage lending in Australia. https://asic.gov.au/regulatory-resources/ find-a-document/reports/rep-586-review-of-reverse-mortgage-lending-in-australia/

Banco de España. (2014). Encuesta Financiera de las Familias. https://www.bde.es/bde/es/areas/estadis/ estadisticas-por/encuestas-hogar/relacionados/Encuesta_Financi/

Banco de España. (2017b). Encuesta Financiera de las Familias (EFF) 2014 : métodos, resultados y cambios desde 2011. Artículos Analíticos.

Bergmann, M., Scherpenzeel, A., \& Börsch-Supan, A. (2019). SHARE Wave 7 Methodology: Panel Innovations and Life Histories. Munich: Munich Center for the Economics of Aging (MEA).

Blay Berrueta, D. (2007). Sistemas de cofinanciación de la dependencia: seguro privado frente a hipoteca inversa. Madrid: Fundación Mapfre. https://www.fundacionmapfre.org/documentacion/publico/i18n/ catalogo_imagenes/grupo.cmd?path=1036971.

Boletín Oficial del Estado. Ley 41/2007, de 7 de diciembre, por la que se modifica la Ley 2/181, de 25 de marzo, del Mercado Hipotecario y otras normas del sistema hipotecario y financiero, de regulación de las hipotecas inversas y el seguro de dependencia y por la que se establece (2007).

Börsch-Supan, A. (2019). Survey of Health, Ageing and Retirement in Europe (SHARE) Wave 7. Release version: 7.0.0. SHARE-ERIC. Data set. Doi: https://doi.org/10.6103/SHARE.w7.700

Börsch-Supan, A., Brandt, M., Hunkler, C., Kneip, T., Korbmacher, J., Malter, F., et al. (2013). Data resource profile: The survey of health, ageing and retirement in europe (SHARE). International Journal of Epidemiology. https://doi.org/10.1093/ije/dyt088

Browning, M., \& Crossley, T. F. (2001). The life-cycle model of consumption and saving. Journal of Economic Perspectives, 15(3), 3-22.

Cabrero García, J. (2017). La hipoteca inversa: el marco en el que se desenvuelve, visión sociológica, económica y jurídica. UNED. Retrieved from dspace.uah.es/.../TESIS ROCIO LLAMAS RAMOS.pdf 
Coda Moscarola, F., D’Addio, A. C., Fornero, E., \& Rossi, M. (2015). Reverse mortgage: a tool to reduce old age poverty without sacrificing social inclusion. In Ageing in Europe - Supporting Policies for an Inclusive Society (pp. 235-244). De Gruyter. https://doi.org/https://doi.org/10.1515/9783110444 414-023

Colombo, F., Llena-Nozal, A., Mercier, J., \& Tjadens, F. (2011). Help Wanted? Providing and Paying for Long-Term Care. Paris: OECD. https://doi.org/10.1787/9789264097759-en

Costa-Font, J., Gil, J., \& Mascarilla, O. (2010). Housing wealth and housing decisions in old age: Sale and reversion. Housing Studies, 25(3), 375-395. https://doi.org/10.1080/02673031003711014

de España, B. (2017). Guía de acceso a la hipoteca inversa (Vol. 2). Madrid: Banco de España.

de la Maisonneuve, C., \& Oliveira Martins, J. (2015). The future of health and long-term care spending. OECD Journal: Economic Studies, 2014(1), 61-96. https://doi.org/10.1787/eco_studies-2014-5jz0v 44s66nw

De Nardi, M., French, E., \& Jones, J. B. (2010). Why do the elderly save? The role of medical expenses. Journal of Political Economy, 118(1), 39-75. https://doi.org/10.1086/651674

del Pozo-Rubio, R., Mínguez-Salido, R., Pardo-García, I., \& Escribano-Sotos, F. (2019). Catastrophic longterm care expenditure: Associated socio-demographic and economic factors. The European Journal of Health Economics. https://doi.org/10.1007/s10198-019-01031-8

Dushi, I., \& Webb, A. (2004). Household annuitization decisions simulations and empirical analyses. Journal of Pension Economics and Finance, 3(2), 109-143. https://doi.org/10.1017/S1474747204001696

Eggleston, K. N., \& Mukherjee, A. (2019). Financing longevity: The economics of pensions, health, and long-term care: Introduction to the special issue. Journal of the Economics of Ageing, 13, 1-6. https:// doi.org/10.1016/j.jeoa.2018.10.001

Commission, E. (2018). The 2018 Ageing Report: economic and budgetary projections for the EU Member States (2016-2070). Luxembourg: Publications Office of the European Union. https://doi. org/10.2765/615631

Eurostat. (2019a). Economy and finance. Eurostat. Retrived 7 August 2019, from, https://appsso.eurostat. ec.europa.eu/nui/show.do?dataset=nama_10_gdp\&lang=en.

Eurostat. (2019b). Population and social conditions. Eurostat.

Eurostat. (2020). Old-age-dependency ratio. https://ec.europa.eu/eurostat/web/products-datasets/-/tps00198.

Fundación de Estudios Financieros. (2018). Sector Asegurador: impacto de las tendencias macroeconómicas y demográficas (No. 15). Madrid.

García Díaz, M. Á. (2019). Situación actual y perspectivas del sistema público español de pensiones. Papeles de Economía Española, 161, 17-28. https://www.funcas.es/publicaciones_new/publicaciones.aspx

Haurin, D., Ma, C., Moulton, S., Schmeiser, M., Seligman, J., \& Shi, W. (2016). Spatial variation in reverse mortgages usage: House price dynamics and consumer selection. Journal of Real Estate Finance and Economics, 53(3), 392-417. https://doi.org/10.1007/s11146-014-9463-2

Inkmann, J., Lopes, P., \& Michaelides, A. (2011). How deep is the annuity market participation puzzle? Review of Financial Studies, 24(1), 279-319. https://doi.org/10.1093/rfs/hhq080

Instituto Nacional de Estadística. (2019a). Encuesta de Condiciones de Vida. Madrid: Instituto Nacional de Estadística. Retrived 6 August 2019, from, https://www.ine.es/.

Instituto Nacional de Estadística. (2019). Estadística del Padrón continuo. Madrid: Instituto Nacional de Estadística.

Instituto Nacional de Estadística. (2019c). Indicadores demográficos básicos. Madrid: Instituto Nacional de Estadística. Retrived 1 August 2019, from, https://www.ine.es/.

Knaack, P., Miller, M., \& Stewart, F. (2020). Reverse Mortgages, Financial Inclusion, and Economic Development. Potential Benefit and Risks (No. 9134).

Koijen, R. S. J., Van Nieuwerburgh, S., \& Yogo, M. (2016). Health and mortality delta: Assessing the welfare cost of household insurance choice. Journal of Finance, 71(2), 957-1010. https://doi.org/10.1111/ jofi. 12273

Lennartz, C., Arundel, R., \& Ronald, R. (2016). Younger adults and homeownership in europe through the global financial crisis. Population, Space and Place, 22(8), 823-835. https://doi.org/10.1002/psp.1961

López-Rodríguez, D., \& Matea, M. de los L. (2019). Evolución reciente del mercado del alquiler de vivienda en España. Boletín Económico, 3.

Michelangeli, V. (2010). Does it pay to get a reverse mortgage? https://people.bu.edu/rking/GLMMsept/ michelangeli_sep15.pdf.

Mudrazija, S., \& Butrica, B. A. (2017). Homeownership, social insurance, and old-age security in the United states and Europe. Boston. https://crr.bc.edu/working-papers/homeownership-social-insuranceand-old-age-security-in-the-united-states-and-europe/.

Nakajima, M., \& Telyukova, I. A. (2017). Reverse mortgage loans: A quantitative analysis. The Journal of Finance, 72(2), 911-950. https://doi.org/10.1111/jofi.12489 
OECD. (2013). Pensions at a Glance 2013: OECD and G20 Indicators. Paris: OECD Publishing. https:// doi.org/10.1787/pension_glance-2017-en\%0AISBN

OECD. (2017a). Pensions at a Glance 2017: OECD and G20 Indicators. Paris: OECD Publishing. https:// doi.org/10.1787/pension_glance-2017-en\%0AISBN

OECD. (2017b). Preventing ageing unequally. Paris: OECD Publishing. https://doi.org/10.1787/97892 64279087-en

OECD. (2019). OECD Health Statistics 2019. https://www.oecd.org/health/health-systems/health-data.htm.

OECD. (2020). OECD Economic Outlook, Vol. 2020, Issue 1, No. 107. Paris: OECD Publishing.

Ong, R. (2008). Unlocking housing equity through reverse mortgages: The case of elderly homeowners in Australia. International Journal of Housing Policy, 8(1), 61-79. https://doi.org/10.1080/1461671070 1817166

Orts Santos, M. J. (2012). La hipoteca inversa. Universidad de Salamanca.

Pareja-Eastaway, M., \& Sánchez-Martínez, T. (2017). More social housing? A critical analysis on social housing provision in Spain. Critical Housing Analysis, 4(1), 124-131. https://doi.org/10.13060/23362 839.2017.4.1.331

Pashchenko, S. (2013). Accounting for non-annuitization. Journal of Public Economics, 98, 53-67. https:// doi.org/10.1016/j.jpubeco.2012.11.005

Piggott, J., \& Woodland, A. (2016). Handbook of the economics of population aging. Amsterdam: Elsevier B.V.

Pittini, A., Koessl, G., Dijol, J., Lakatos, E., \& Ghekiere, L. (2017). The state of housing in the EU 2017. Brussels: Housing Europe.

Redfoot, D. L., Scholen, K., \& Brown, S. K. (2007). Reverse mortgages: Niche product or mainstream solution? Report on the 2006 AARP national survey of reverse mortgage shoppers. Washington, DC.

Shan, H. (2011). Reversing the trend: The recent expansion of the reverse mortgage market. Real Estate Economics, 39(4), 743-768. https://doi.org/10.1111/j.1540-6229.2011.00310.x

Simón-Moreno, H. (2019). The regulation of reverse mortgages as a source of income in retirement: Policy options and legal drivers. Journal of Housing and the Built Environment, 34, 1005-1022. https://doi. org/10.1007/s10901-019-09653-3

Toral Lara, E. (2008). El contrato de renta vitalicia. Universidad de Salamanca.

Turra, C. M., \& Mitchell, O. S. (2007). The impact of health status and out-of-pocket medical expenditures on annuity valuation (No. 393). https://repository.upenn.edu/prc_papers/393.

Yaari, M. E. (1965). Uncertain lifetime, life insurance, and the theory of the consumer. The Review of Economic Studies, 32(2), 137-150. https://doi.org/10.2307/2296058

Yogo, M. (2016). Portfolio choice in retirement: Health risk and the demand for annuities, housing, and risky assets. Journal of Monetary Economics, 80, 17-34. https://doi.org/10.1016/j.jmoneco.2016.04.008

Publisher's Note Springer Nature remains neutral with regard to jurisdictional claims in published maps and institutional affiliations. 